\title{
External Ear Basal Cell Carcinoma
}

National Cancer Institute

\section{Source}

National Cancer Institute. External Ear Basal Cell Carcinoma. NCI Thesaurus. Code C6082.

A basal cell carcinoma that arises from the skin of the external ear. 